\title{
Profil Implementasi Model Shared pada Pembelajaran IPA Terpadu di Indonesia: Kajian Literatur (2012-2021)
}

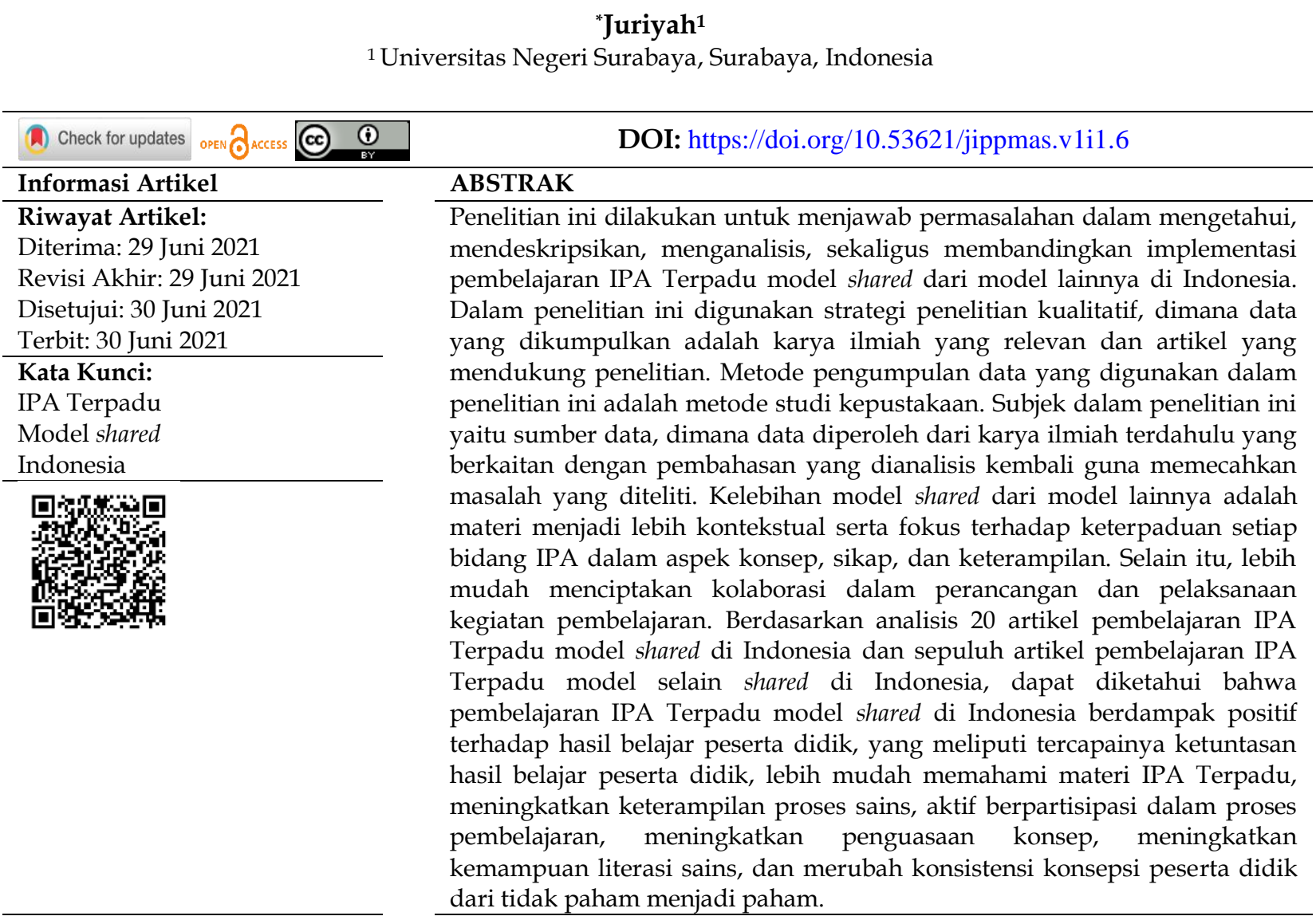

\section{PENDAHULUAN}

Ilmu Pengetahuan Alam (IPA) dapat diartikan sebagai ilmu yang fokus terhadap penguasaan pengetahuan berupa konsep, fakta, prinsip, hukum, dan proses penemuan yang berkaitan dengan alam baik secara sistematis maupun matematis. Departemen Pendidikan Nasional Indonesia menyatakan bahwa Ilmu Pengetahuan Alam (IPA) berkaitan dengan proses mencari tahu atau mengetahui alam secara sistematis, penguasaan pengetahuan yang berupa konsep, fakta, prinsip, serta dianggap sebagai proses penemuan yang sangat penting untuk dipelajari. Mitarlis menyatakan bahwa Ilmu Pengetahuan Alam diartikan sebagai pengetahuan yang tersusun secara teratur dan sistematis yang berlaku untuk umum, serta berupa kumpulan data hasil pengamatan dan percobaan. Sehingga Ilmu Pengetahuan Alam tidak hanya diartikan sebagai penguasaan pengetahuan berupa konsep, fakta, dan prinsip, namun juga suatu proses penemuan. Menurut Karso, Ilmu Pengetahuan Alam (IPA) adalah pengetahuan yang diuji kebenarannya melalui suatu metode ilmiah.

Pembelajaran Ilmu Pengetahuan Alam berisi empat hal, yaitu isi atau muatan sains; sikap atau watak ilmiah; proses; dan teknologi. Menurut Kurikulum 2013, pembelajaran Ilmu Pengetahuan Alam (IPA) menekankan peserta didik untuk belajar secara aktif dalam hal keterampilan, konsep, dan prinsip. Peserta didik memperoleh pengalaman melalui kegiatan yang telah mereka lakukan. Pada hakikatnya, Ilmu Pengetahuan Alam 
(IPA) terdiri atas empat unsur. Pertama, sikap: rasa ingin tahu tentang suatu benda; makhluk hidup; fenomena alam; dan hubungan sebab akibat yang dapat memecahkan suatu permasalahan yang ditimbulkan. Kedua, proses: langkah pemecahan masalah melalui metode ilmiah; metode ilmiah berupa penyusunan hipotesis; perancangan eksperimen; evaluasi; pengukuran; dan kesimpulan. Ketiga, hasil: meliputi prinsip; teori; fakta; dan hukum. Keempat, aplikasi: penerapan konsep ilmu pengetahuan alam (IPA) dalam kehidupan sehari-hari. Empat unsur utama tersebut harus ada dalam setiap pembelajaran IPA (Kemendikbud, 2013).

Perkembangan ilmu pengetahuan dan teknologi, serta peningkatan mutu pendidikan membuat pemerintah (Departemen Pendidikan dan Kebudayaan) ikut andil dalam peningkatan mutu dan kualitas guru. Untuk menyesuaikan perkembangan ilmu pengetahuan dan teknologi, maka peningkatan kualitas pembelajaran Ilmu Pengetahuan Alam dijadikan bekal kemampuan dasar yang harus ditanamkan terhadap peserta didik. Pembelajaran Ilmu Pengetahuan Alam dikembangkan sebagai mata pelajaran integrated science, bukan sebagai disiplin ilmu yang terpisah-pisah (Kemendikbud, 2013). Dalam hal ini, Kurikulum 2013 menghendaki pembelajaran Ilmu Pengetahuan Alam diajarkan secara terpadu, baik dalam satu disiplin ilmu maupun terpadu antar mata pelajaran.

Pembelajaran terpadu adalah salah satu model implementasi kurikulum yang dianjurkan untuk diaplikasikan pada jenjang pendidikan Sekolah Dasar (SD) dan Sekolah Menengah Pertama (SMP), namun juga tidak menutup kemungkinan untuk dikembangkan pada jenjang Sekolah Menengah Atas (SMA). Hal ini bergantung pada kecenderungan materi-materi yang memiliki potensi untuk dipadukan dalam satu tema tertentu. Pembelajaran terpadu merupakan suatu pembelajaran yang memadukan lebih dari satu materi pembelajaran dari berbagai standar kompetensi dan kompetensi dasar dari satu atau beberapa mata pelajaran. Melalui pembelajaran IPA terpadu, peserta didik dapat memperoleh pengalaman secara langsung, sehingga dapat menambah kemampuan untuk menerapkan konsep yang telah dipelajari.

Pembelajaran model shared merupakan pembelajaran yang menggabungkan kompetensi dasar antar mata pelajaran yang berbeda. Menurut Fogarty, Pembelajaran IPA terpadu model shared merupakan pembelajaran terpadu yang menggunakan pendekatan antar bidang studi, menggabungkan dua bidang studi dengan menetapkan prioritas kurikuler dan menemukan keterampilan, konsep, dan sikap yang beririsan dalam beberapa bidang studi. Pembelajaran IPA terpadu model shared adalah model pembelajaran dengan menggabungkan atau memadukan antara dua mata pelajaran yang saling melengkapi, dimana dalam perencanaan atau pengajarannya menciptakan satu fokus pada konsep, keterampilan, serta sikap. Penggabungan antara konsep pelajaran, keterampilan, dan sikap yang saling berhubungan satu sama lain dinaungi dalam satu tema. Jadi, model pembelajaran terpadu tipe shared adalah model keterpaduan yang memadukan beberapa sub tema menjadi sebuah fokus pada topik utama. Dalam penelitian Sakti (2014) menyebutkan bahwa pembelajaran IPA terpadu tipe shared dapat meningkatkan kemampuan berpikir kritis dan motivasi belajar siswa secara signifikan dibandingkan dengan siswa yang mendapatkan pembelajaran model direct instruction.

Manfaat dari model shared adalah dapat meningkatkan aktivitas belajar peserta didik, diantaranya adalah peserta didik mendengarkan penjelasan guru; merespon pertanyaan guru; mengajukan pertanyaan; melakukan pengamatan; kerja sama dalam kelompok; dan menyelesaikan tugas. Kelebihan model shared dari model lainnya adalah lebih 
mampu dalam hal mentransfer konsep secara lebih mendalam. Menurut Fogarty, kelemahan model shared daripada model lainnya terletak pada penyusunan rencana model pembelajaran, karena diperlukan kerjasama guru antar mata pelajaran yang berbeda sehingga membutuhkan lebih banyak waktu untuk mendiskusikannya.

\section{METODE PENELITIAN}

\section{Latar Belakang Umum}

Berdasarkan hasil pengamatan pembelajaran Ilmu Pengetahuan Alam di lapangan menunjukkan bahwa pembelajaran IPA yang diberikan guru belum sesuai dengan kurikulum 2013. Selain itu, pembelajaran IPA di sekolah masih jarang dikaitkan dengan mata pelajaran lain yang masih berkaitan. Hal ini tentunya mengurangi keefisienan kegiatan belajar mengajar. Dalam hal ini, diharapkan pembelajaran IPA terpadu dapat membangun pemikiran konsep yang baik dan memberi makna kepada peserta didik dalam memahami alam di sekitar.

\section{Subjek Penelitian}

Subjek dalam penelitian ini adalah sumber data penelitian. Sumber data yang digunakan dalam penelitian ini adalah data dari karya-karya ilmiah terdahulu yang berkaitan dengan pembahasan penelitian yang dianalisis kembali untuk memecahkan permasalahan yang diteliti.

\section{Instrumen dan Prosedur}

Dalam menyelesaikan penelitian ini digunakan strategi penelitian kualitatif, yaitu data yang dikumpulkan berupa karya ilmiah yang relevan dan artikel yang mendukung. Definisi penelitian kualitatif menurut Bogdan dan Taylor adalah penelitian yang menghasilkan data deskriptif berupa kata-kata tertulis atau lisan dari orang-orang dan perilaku yang dapat diamati. Bogdan dan Taylor menyatakan bahwa penelitian kualitatif merupakan prosedur penelitian yang menghasilkan data deskriptif berupa kata-kata tertulis maupun lisan dari orang-orang dan perilaku yang diamati. Menurut Sugiyono (2013), penelitian kualitatif adalah penelitian yang digunakan untuk meneliti kondisi objek yang alamiah. Objek alamiah yang dimaksud adalah objek yang apa adanya dan tidak dimanipulasi oleh peneliti. Sehingga selama melakukan kajian literatur tentang profil implementasi pembelajaran IPA Terpadu model shared di Indonesia, peneliti tidak mengubah atau memanipulasi data atau informasi yang telah ada.

Metode pengumpulan data dalam penelitian ini adalah metode studi kepustakaan (kajian literatur). Pengumpulan data menggunakan metode studi kepustakaan dilakukan dengan mempelajari topik-topik terkait dengan penelitian yang dilakukan, dan menghimpun atau mengumpulkan data dari berbagai literatur terpercaya yang telah ada sebelumnya. Dalam penelitian ini, peneliti menghimpun dan mengumpulkan data dari penelitian yang relevan dengan penelitian yang diteliti dan dari berbagai artikel yang mendukung permasalahan penelitian ini, yaitu tentang profil implementasi pembelajaran IPA Terpadu model shared di Indonesia dengan menggunakan kajian literatur dari tahun 2012 hingga 2021. Tujuan digunakannya metode studi kepustakaan ini adalah agar memperoleh pengetahuan baru yang kemudian dapat diterima dan dikaji lebih dalam.

Penelitian ini dilakukan berdasarkan studi kepustakaan. Dimana untuk memperoleh data, penulis menganalisis sumber dan data yang telah dikumpulkan sebelumnya dan 
mengandalkan konsep atau teori yang ada untuk kemudian memperoleh jawaban dari masalah yang dibahas dalam penelitian.

\section{Analisis data}

Setelah data terkumpul, langkah selanjutnya adalah menganalisis data. Adapun analisis data dilakukan agar mendapat data yang valid untuk bahan penelitian. Dalam hal ini, peneliti menggunakan dua metode berpikir, yaitu metode induktif dan metode deduktif. Metode induktif adalah metode berpikir yang menarik kesimpulan dari faktor-faktor yang bersifat khusus yang kemudian digeneralisasikan. Metode ini digunakan untuk menarik kesimpulan dari berbagai informasi. Sedangkan metode deduktif adalah metode berpikir yang menarik kesimpulan yang bersifat umum menjadi khusus. Metode ini digunakan untuk menguraikan penafsiran mengenai profil implementasi pembelajaran IPA terpadu model shared di Indonesia dengan menggunakan kajian literatur dari tahun 2012 hingga 2021.

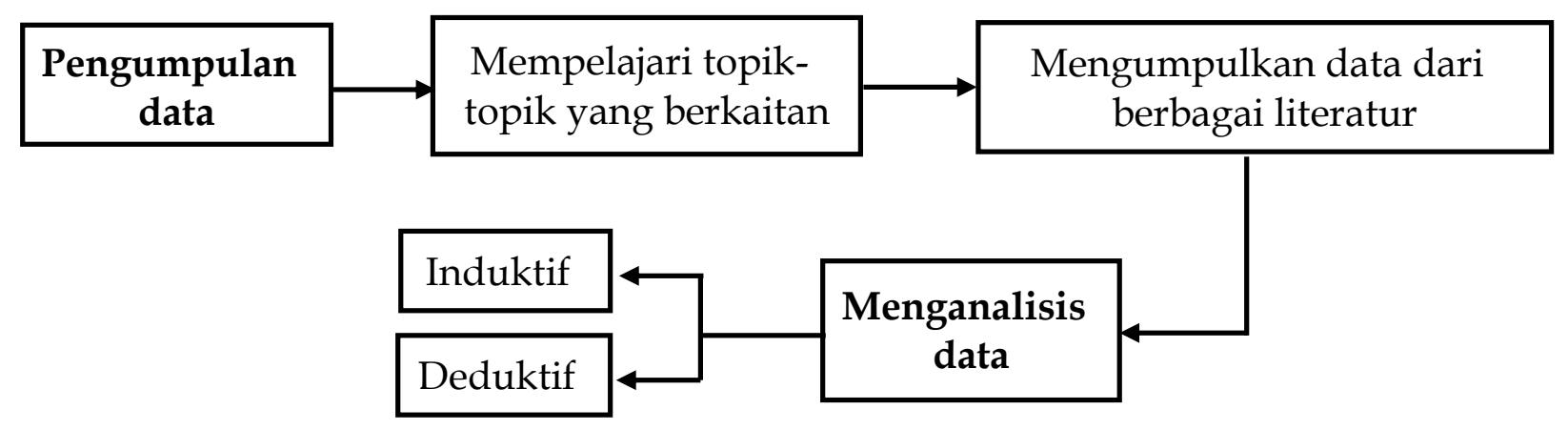

\section{HASIL DAN DISKUSI}

Hasil

Tabel 1. Kajian literatur pembelajaran IPA Terpadu model Shared 2012-2021

\begin{tabular}{|c|c|c|c|}
\hline $\begin{array}{l}\text { Penulis } \\
\text { (Tahun) }\end{array}$ & $\begin{array}{c}\text { Karakteristik } \\
\text { Sampel }\end{array}$ & Desain Penlitian & Temuan \\
\hline $\begin{array}{l}\text { Shofiatun } \\
\text { Nikmah, } \\
\text { Harto Nuroso, } \\
\text { \& Fine } \\
\text { Reffiane (2019) }\end{array}$ & $\begin{array}{l}\text { Subjek penelitian } \\
\text { adalah } 30 \text { peserta } \\
\text { didik kelas IV SDN } \\
\text { Sukorejo } 01 \\
\text { Semarang (kelas } \\
\text { kontrol) dan } 30 \\
\text { peserta didik SDN } \\
\text { Sukorejo } 02 \\
\text { Semarang (kelas } \\
\text { eksperimen). }\end{array}$ & $\begin{array}{l}\text { - Menggunakan } \\
\text { model } \\
\text { pembelajaran } \\
\text { terpadu tipe } \\
\text { shared berbantu } \\
\text { media pop-up book. } \\
\text { - Penelitian } \\
\text { eksperimen } \\
\text { kuantitatif } \\
\text { menggunakan } \\
\text { quasi experiment. } \\
\text { - Desain penelitian } \\
\text { nonequivalent } \\
\text { control group. }\end{array}$ & $\begin{array}{l}\text { - Model pembelajaran } \\
\text { terpadu tipe shared } \\
\text { berbantu media pop- } \\
\text { up book dapat } \\
\text { meningkatkan hasil } \\
\text { belajar peserta didik } \\
\text { kelas IV SDN } \\
\text { Sukorejo } 02 \\
\text { Semarang }\end{array}$ \\
\hline
\end{tabular}




\begin{tabular}{|c|c|c|c|}
\hline $\begin{array}{l}\text { Linaria } \\
\text { Arofatul Ilmi } \\
\text { Uswatun } \\
\text { Khasanah } \\
(2021)\end{array}$ & $\begin{array}{l}\text { Subjek penelitian ini } \\
\text { adalah } 26 \text { peserta } \\
\text { didik kelas IV SDN } \\
\text { Tunjung Mekar } \\
\text { Kalitengah } \\
\text { Lamongan (kelas } \\
\text { eksperimen) dan } 26 \\
\text { peserta didik kelas } \\
\text { IV SDN } \\
\text { Pengangsalan } 2 \\
\text { (kelas kontrol). }\end{array}$ & $\begin{array}{l}\text { - Termasuk } \\
\text { penelitian } \\
\text { pengembangan. } \\
\text { - Menerapkan } \\
\text { metode Dick and } \\
\text { Carey. }\end{array}$ & $\begin{array}{l}\text { - Ada pengaruh } \\
\text { penggunaan media } \\
\text { pembelajaran } \\
\text { terpadu berbasis } \\
\text { saintifik dalam } \\
\text { meningkatkan hasil } \\
\text { belajar peserta didik } \\
\text { kelas IV SDN } \\
\text { Tunjung Mekar. }\end{array}$ \\
\hline $\begin{array}{l}\text { Linaria } \\
\text { Arofatul Ilmi } \\
\text { Uswatun } \\
\text { Khasanah, } \\
\text { Waspodo } \\
\text { Tjipto Subroto, } \\
\text { \& Nasution } \\
\text { (2018) }\end{array}$ & $\begin{array}{l}\text { Subjek penelitian ini } \\
\text { adalah peserta didik } \\
\text { kelas IV SD. }\end{array}$ & $\begin{array}{l}\text { - Metode yang } \\
\text { digunakan adalah } \\
\text { Dick and Carey } \\
\text { - Desain penelitian } \\
\text { ini adalah pretest- } \\
\text { posttest group. }\end{array}$ & $\begin{array}{l}\text { - Rata-rata } \\
\text { pengamatan } \\
\text { keterlaksanaan } \\
\text { pembelajaran } \\
\text { memperoleh } \\
\text { persentase 93\% dan } \\
\text { berkategori sangat } \\
\text { baik. }\end{array}$ \\
\hline $\begin{array}{l}\text { Surahman Oki } \\
\text { Wiyono \& } \\
\text { Yuliani (2013) }\end{array}$ & $\begin{array}{l}\text { Subjek penelitian } \\
\text { dalam uji coba } \\
\text { kelompok kecil, } \\
\text { yaitu } 12 \text { peserta } \\
\text { didik perwakilan } \\
\text { kelas VIII A SMP } \\
\text { Negeri } 1 \text { Babat }\end{array}$ & $\begin{array}{l}\text { - Menggunakan } \\
\text { jenis penelitian } \\
\text { pengembangan } \\
\text { (development } \\
\text { research). }\end{array}$ & $\begin{array}{l}\text { - Respon peserta } \\
\text { didik dalam } \\
\text { pembelajaran IPA } \\
\text { Terpadu dan } \\
\text { perangkat } \\
\text { pembelajaran adalah } \\
\text { positif. }\end{array}$ \\
\hline $\begin{array}{l}\text { Rosa Diana } \\
\text { Syifaul } \\
\text { Qolbiyah, } \\
\text { Abdul Aziz } \\
\text { Abdullah, \& } \\
\text { Beni Setiawan } \\
\text { (2013) }\end{array}$ & $\begin{array}{l}\text { Penelitian dilakukan } \\
\text { di SMPN } 1 \text { Baureno } \\
\text { Sampel yang dipilih } \\
\text { adalah peserta didik } \\
\text { kelas VIII A dengan } \\
\text { jumlah siswa } 34 .\end{array}$ & $\begin{array}{l}\text { - Menggunakan } \\
\text { jenis penelitian } \\
\text { deskriptif dengan } \\
\text { Pre Experimental } \\
\text { Design. } \\
\text { - Menggunakan } \\
\text { rancangan Pre-test } \\
\text { Post-test Group } \\
\text { Design. }\end{array}$ & $\begin{array}{l}\text { - Secara keseluruhan } \\
\text { peserta didik merasa } \\
\text { lebih mudah } \\
\text { memahami materi } \\
\text { IPA Terpadu } \\
\text { dengan persentase } \\
\text { 94,12\%. }\end{array}$ \\
\hline $\begin{array}{l}\text { Endria Retna } \\
\text { Cahyani, } \\
\text { Herlina } \\
\text { Fitrihidajati, \& } \\
\text { Eko Hariyono } \\
\text { (2013) }\end{array}$ & $\begin{array}{l}\text { Sasaran dalam } \\
\text { penelitian ini adalah } \\
33 \text { peserta didik } \\
\text { kelas VII SMP } \\
\text { Negeri } 1 \text { Tugu } \\
\text { Trenggalek. }\end{array}$ & $\begin{array}{l}\text { - Jenis penelitian } \\
\text { pengembangan. } \\
\text { - Model } \\
\text { pengembangan } \\
\text { yang digunakan } \\
\text { diadaptasi dari } \\
\text { model Dick and } \\
\text { Carey. }\end{array}$ & $\begin{array}{l}\text { - Perangkat } \\
\text { pembelajaran yang } \\
\text { dikembangkan } \\
\text { dinyatakan layak } \\
\text { dengan persentase } \\
\text { kelayakan } 84,32 \%\end{array}$ \\
\hline
\end{tabular}




\begin{tabular}{|c|c|c|c|}
\hline $\begin{array}{l}\text { Muhammad } \\
\text { Yusuf \& Ana } \\
\text { Ratna Wulan } \\
(2015)\end{array}$ & $\begin{array}{l}\text { Sampel dipilih } \\
\text { secara acak kelas } \\
\text { (random class), yaitu } \\
\text { peserta didik kelas } \\
\text { VII A dan VII B } \\
\text { dengan jumlah } \\
\text { peserta didik } \\
\text { masing-masing kelas } \\
\text { adalah } 24 \text { peserta } \\
\text { didik. }\end{array}$ & $\begin{array}{l}\text { - Metode penelitian } \\
\text { menggunakan } \\
\text { penelitian } \\
\text { eksperimen semu } \\
\text { (quasi experiment). } \\
\text { - Menggunakan } \\
\text { desain penelitian } \\
\text { The Matching-Only } \\
\text { Pretest-Posttest } \\
\text { Control Group } \\
\text { Design. }\end{array}$ & $\begin{array}{l}\text { - Profil indikator } \\
\text { keterampilan proses } \\
\text { sains diperoleh rata- } \\
\text { 4N-Gain peserta } \\
\text { didik pada kelas } \\
\text { shared 0,55, yang } \\
\text { berarti } \\
\text { meningkatkan } \\
\text { keterampilan proses } \\
\text { sains peserta didik. }\end{array}$ \\
\hline $\begin{array}{l}\text { Chandra Okta } \\
\text { Fiandi (2015) }\end{array}$ & $\begin{array}{l}\text { Sampel penelitian } \\
\text { adalah peserta didik } \\
\text { kelas VIII SMP } \\
\text { Negeri } 1 \text { Kecamatan } \\
\text { Mapat Tunggul } \\
\text { Sumatera Barat yang } \\
\text { dibagi menjadi dua } \\
\text { kelas, yaitu kelas } \\
\text { kontrol sebanyak } 32 \\
\text { peserta didik dan } \\
\text { kelas eksperimen } \\
\text { sebanyak } 29 \text { peserta } \\
\text { didik. }\end{array}$ & $\begin{array}{l}\text { - Metode penelitian } \\
\text { menggunakan } \\
\text { quasi experiment } \\
\text { (eksperimen } \\
\text { semu). } \\
\text { - Menggunakan } \\
\text { desain penelitian } \\
\text { Matching-Only } \\
\text { Pretest-Posttest } \\
\text { Control Group } \\
\text { Design. }\end{array}$ & $\begin{array}{l}\text { - Model pembelajaran } \\
\text { STAD dapat lebih } \\
\text { meningkatkan hasil } \\
\text { belajar aspek } \\
\text { kognitif peserta } \\
\text { didik pada materi } \\
\text { pokok cahaya } \\
\text { menggunakan } \\
\text { keterpaduan materi } \\
\text { model shared. }\end{array}$ \\
\hline $\begin{array}{l}\text { Nita Novianti } \\
\text { \& Any Fitriani } \\
(2015)\end{array}$ & $\begin{array}{l}\text { Sampel yang } \\
\text { digunakan adalah } \\
\text { dua kelas VII SMP di } \\
\text { Kota Sukabumi yang } \\
\text { memiliki nilai rata- } \\
\text { rata mata pelajaran } \\
\text { IPA yang hampir } \\
\text { sama. }\end{array}$ & $\begin{array}{l}\text { - Menggunakan } \\
\text { metode penelitian } \\
\text { kuasi eksperimen, } \\
\text { dengan desain } \\
\text { penelitian The } \\
\text { Matching-Only } \\
\text { Pretest-Posttest } \\
\text { Control Group. } \\
\text { - Dilakukan tes } \\
\text { baik sebelum } \\
\text { maupun sesudah } \\
\text { perlakuan pada } \\
\text { kedua kelompok. }\end{array}$ & $\begin{array}{l}\text { - Hasil pengamatan } \\
\text { terhadap peserta } \\
\text { didik menunjukkan } \\
\text { bahwa peserta didik } \\
\text { aktif berpartisipasi } \\
\text { dalam setiap } \\
\text { tahapan kegiatan } \\
\text { pembelajaran IPA } \\
\text { tipe webbed dan } \\
\text { shared. }\end{array}$ \\
\hline $\begin{array}{l}\text { Chandra Okta } \\
\text { Fiandi (2015) }\end{array}$ & $\begin{array}{l}\text { Sampel penelitian ini } \\
\text { adalah peserta didik } \\
\text { kelas VIII SMP } \\
\text { Negeri } 1 \text { Kecamatan } \\
\text { Mapat Tunggul } \\
\text { Sumatera Barat. }\end{array}$ & $\begin{array}{l}\text { - Menggunakan } \\
\text { metode penelitian } \\
\text { quasi experiment. } \\
\text { - Menggunakan } \\
\text { desain Matching- } \\
\text { Only Pretest- } \\
\text { Posttest Control } \\
\text { Group Design. }\end{array}$ & $\begin{array}{l}\text { - Model pembelajaran } \\
\text { STAD dengan } \\
\text { menggunakan } \\
\text { keterpaduan materi } \\
\text { IPA tipe shared } \\
\text { dapat meningkatkan } \\
\text { hasil belajar aspek } \\
\text { kognitif peserta } \\
\text { didik pada materi } \\
\text { pokok cahaya. }\end{array}$ \\
\hline
\end{tabular}




\begin{tabular}{|c|c|c|c|}
\hline $\begin{array}{l}\text { Muhammad } \\
\text { Yusuf \& Ana } \\
\text { Ratna Wulan } \\
(2016)\end{array}$ & $\begin{array}{l}\text { Sampel penelitian ini } \\
\text { adalah peserta didik } \\
\text { kelas VII A dan VII B } \\
\text { SMP Negeri di } \\
\text { Kabupaten } \\
\text { Bulungan, } \\
\text { Kalimantan Utara. }\end{array}$ & $\begin{array}{l}\text { - Menggunakan } \\
\text { metode penelitian } \\
\text { quasi experiment. } \\
\text { - Menggunakan } \\
\text { The Matching-Only } \\
\text { Pretest-Posttest } \\
\text { Control Group } \\
\text { Design. }\end{array}$ & $\begin{array}{l}\text { - Penguasaan konsep } \\
\text { kelas model shared } \\
\text { lebih unggul } \\
\text { dibandingkan kelas } \\
\text { model webbed. }\end{array}$ \\
\hline $\begin{array}{l}\text { Nita Novianti } \\
\text { \& Any Fitiriani } \\
(2016)\end{array}$ & $\begin{array}{l}\text { Populasi penelitian } \\
\text { ini adalah peserta } \\
\text { didik kelas VII di } \\
\text { salah satu SMP di } \\
\text { Kota Sukabumi. } \\
\text { Penentuan sampel } \\
\text { menggunakan teknik } \\
\text { purposive sampling } \\
\text { dengan cara memilih } \\
\text { dua kelas yang } \\
\text { memiliki nilai rata- } \\
\text { rata mata pelajaran } \\
\text { IPA semester } 1 \text { yang } \\
\text { hampir sama. }\end{array}$ & $\begin{array}{l}\text { - Menggunakan } \\
\text { metode penelitian } \\
\text { kuasi eksperimen, } \\
\text { dengan desain } \\
\text { penelitian The } \\
\text { Matching Only } \\
\text { Pretest-Posttest } \\
\text { Control Group. }\end{array}$ & $\begin{array}{l}\text { - Penerapan kegiatan } \\
\text { pemanfaatan } \\
\text { sampah dengan } \\
\text { pendekatan inkuiri } \\
\text { terbimbing pada } \\
\text { kelas pembelajaran } \\
\text { IPA Terpadu model } \\
\text { shared mengalami } \\
\text { peningkatan } \\
\text { keterampilan proses } \\
\text { sains peserta didik. }\end{array}$ \\
\hline $\begin{array}{l}\text { Didin } \\
\text { Ardianto \& } \\
\text { Bibin Rubini } \\
(2016)\end{array}$ & $\begin{array}{l}\text { Subjek penelitian } \\
\text { yang digunakan } \\
\text { adalah peserta didik } \\
\text { kelas VIII B di salah } \\
\text { satu SMP Negeri } \\
\text { Kota Bandung. }\end{array}$ & $\begin{array}{l}\text { - Menggunakan } \\
\text { metode penelitian } \\
\text { kuasi eksperimen. } \\
\text { - Desain penelitian } \\
\text { yang digunakan } \\
\text { adalah one group } \\
\text { pre-test post-test } \\
\text { design. }\end{array}$ & $\begin{array}{l}\text { - Pembelajaran } \\
\text { terpadu model } \\
\text { shared dapat } \\
\text { meningkatkan } \\
\text { kemampuan literasi } \\
\text { sains aspek konten, } \\
\text { proses, dan sikap } \\
\text { sains. }\end{array}$ \\
\hline $\begin{array}{l}\text { Rahmi } \\
\text { Faradisya } \\
\text { Ekapti (2016) }\end{array}$ & $\begin{array}{l}\text { Sampel dalam } \\
\text { penelitian ini adalah } \\
\text { kelas VIII A } \\
\text { sebanyak } 32 \text { peserta } \\
\text { didik dan kelas VIII } \\
\text { B sebanyak } 30 \\
\text { peserta didik. }\end{array}$ & $\begin{array}{l}\text { - Menggunakan } \\
\text { metode penelitian } \\
\text { kuasi eksperimen. } \\
\text { - Desain penelitian } \\
\text { yang digunakan } \\
\text { adalah } \\
\text { nonequivalent } \\
\text { control group } \\
\text { design. }\end{array}$ & $\begin{array}{l}\text { - Persentase } \\
\text { keterlaksanaan } \\
\text { pembelajaran IPA } \\
\text { Terpadu model PBL } \\
\text { tipe shared (kelas } \\
\text { eksperimen) sebesar } \\
\text { 93,09\%. }\end{array}$ \\
\hline $\begin{array}{l}\text { Rahmi } \\
\text { Faradisya } \\
\text { Ekapti \& } \\
\text { Mochammed } \\
\text { Ahied (2016) }\end{array}$ & $\begin{array}{l}\text { Penelitian dilakukan } \\
\text { di salah satu kelas } \\
\text { VIII SMP Negeri di } \\
\text { Kabupaten Gresik. }\end{array}$ & $\begin{array}{l}\text { - Metode penelitian } \\
\text { yang digunakan } \\
\text { adalah weak } \\
\text { experiment dengan } \\
\text { The One Group } \\
\text { Pretest-Posttest } \\
\text { Design. }\end{array}$ & $\begin{array}{l}\text { - Pembelajaran IPA } \\
\text { Terpadu model } \\
\text { shared merubah } \\
\text { secara signifikan } \\
\text { konsistensi konsepsi } \\
\text { peserta didik SMP } \\
\text { untuk konsep } \\
\text { tekanan. }\end{array}$ \\
\hline
\end{tabular}




\begin{tabular}{|c|c|c|c|}
\hline $\begin{array}{l}\text { Nessa Aqila, } \\
\text { Ratnawulan, \& } \\
\text { Gusnedi (2019) }\end{array}$ & $\begin{array}{l}\text { Subjek penelitian ini } \\
\text { adalah seluruh } \\
\text { peserta didik kelas } \\
\text { VII semester } 1 \text { SMPN } \\
4 \text { Padang. }\end{array}$ & $\begin{array}{l}\text { - Jenis penelitian } \\
\text { ini adalah Quasi } \\
\text { Experiment } \\
\text { Research } \\
\text { (Penelitian } \\
\text { Eksperimental- } \\
\text { Semu). } \\
\text { - Desain penelitian } \\
\text { yang digunakan } \\
\text { adalah } \\
\text { Randomized } \\
\text { Control Group } \\
\text { Only Design. }\end{array}$ & $\begin{array}{l}\text { - Buku siswa IPA } \\
\text { Terpadu model } \\
\text { shared tema kohesi } \\
\text { dan adhesi pada } \\
\text { lingkungan efektif } \\
\text { untuk aspek } \\
\text { keterampilan, tetapi } \\
\text { tidak aktif untuk } \\
\text { aspek pengetahuan. }\end{array}$ \\
\hline $\begin{array}{l}\text { Nurhaningtyas } \\
\text { Agustin (2019) }\end{array}$ & $\begin{array}{l}\text { Subjek penelitian ini } \\
\text { adalah kelas VIII-E } \\
\text { sebagai kelas } \\
\text { eksperimen dan } \\
\text { kelas VIII-F sebagai } \\
\text { kelas kontrol dengan } \\
\text { jumlah peserta didik } \\
\text { masing-masing kelas } \\
\text { adalah } 36 .\end{array}$ & $\begin{array}{l}\text { - Merupakan } \\
\text { penelitian True } \\
\text { Experiment Design. } \\
\text { - Menggunakan } \\
\text { rancangan Control } \\
\text { Group Pre Test } \\
\text { Post Test Design. }\end{array}$ & $\begin{array}{l}\text { - Pembelajaran } \\
\text { menggunakan } \\
\text { model pembelajaran } \\
7 E \text { dalam IPA } \\
\text { Terpadu tema } \\
\text { Energi Biomassa } \\
\text { dapat meningkatkan } \\
\text { keterampilan proses } \\
\text { sains sebesar } 0,73 \text {. }\end{array}$ \\
\hline $\begin{array}{l}\text { S. Rahmiwati, } \\
\text { Ratnawulan, \& } \\
\text { Yohandri } \\
\text { (2018) }\end{array}$ & $\begin{array}{l}\text { Subjek penelitian ini } \\
\text { adalah peserta didik } \\
\text { kelas VII SMPN } 13 \\
\text { Padang. }\end{array}$ & $\begin{array}{l}\text { - Metode penelitian } \\
\text { yang digunakan } \\
\text { adalah pre- } \\
\text { experimental } \\
\text { design. } \\
\text { - Desain penelitian } \\
\text { adalah one group } \\
\text { pre-test and post- } \\
\text { test design. }\end{array}$ & $\begin{array}{l}\text { - Kemampuan } \\
\text { pengetahuan peserta } \\
\text { didik meningkat } \\
\text { secara signifikan } \\
\text { dan dikategorikan } \\
\text { tinggi. }\end{array}$ \\
\hline $\begin{array}{l}\text { Siti Hesniyatul } \\
\text { Jamila (2019) }\end{array}$ & $\begin{array}{l}\text { Sumber data } \\
\text { penelitian ini adalah } \\
\text { informan. Penelitian } \\
\text { ini dilakukan di } \\
\text { lembaga pendidikan } \\
\text { yang berada di } \\
\text { naungan yayasan } \\
\text { Muhammad Ya'qub } \\
\text { Jombang. }\end{array}$ & $\begin{array}{l}\text { - Menggunakan } \\
\text { pendekatan } \\
\text { kualitatif. } \\
\text { - Informan } \\
\text { penelitian ini } \\
\text { adalah dewan } \\
\text { pembina, ketua } \\
\text { yayasan, kepala } \\
\text { sekolah, bagian } \\
\text { kurikulum, } \\
\text { pendidik, peserta } \\
\text { didik, observasi, } \\
\text { dan dokumentasi. }\end{array}$ & $\begin{array}{l}\text { - Pembelajaran } \\
\text { terpadu pelajaran } \\
\text { Biologi model shared } \\
\text { di lembaga } \\
\text { pendidikan yang } \\
\text { berada di naungan } \\
\text { yayasan } \\
\text { Muhammad Ya'qub } \\
\text { Jombang lebih } \\
\text { unggul karena ada } \\
\text { pelatihan ilmu } \\
\text { kependidikan dalam } \\
\text { pembelajaran. }\end{array}$ \\
\hline
\end{tabular}




\begin{tabular}{llll}
\hline Yeni & Subjek penelitian & $\bullet$ Menggunakan & $\bullet$ Model pembelajaran \\
Suryaningsih & adalah 39 peserta & model & terpadu model \\
$(2016)$ & didik kelas XI IPA & pembelajaran & shared dapat \\
& Madrasah Aliyah & terpadu model & meningkatkan \\
& PUI Maja Kabupaten & shared. & kecerdasan spiritual \\
& Majalengka & • Jenis penelitian & peserta didik. \\
& & eksperimental. & \\
\hline
\end{tabular}

\section{DISKUSI}

\section{Karakteristik, Kelebihan, dan Kekurangan dari Model Shared}

Model shared bertujuan untuk menggabungkan dua mata pelajaran yang saling melengkapi, sehingga dalam pelaksanaannya menciptakan suatu fokus konsep tertentu. Kelebihan model shared adalah materi pelajaran menjadi lebih kontekstual serta menunjukkan keterpaduan bidang-bidang IPA dalam aspek konsep, sikap, dan keterampilan. Selain itu, karena dalam merancang dan melaksanakan pembelajaran melibatkan dua guru dalam satu tim, maka lebih mudah menciptakan kolaborasi dalam perancangan dan pelaksanaan pembelajaran. Kekurangan model shared yaitu karena melibatkan dua guru dalam satu tim, maka perencanaan pembelajaran diperkirakan memakan waktu lebih banyak yang disebabkan memerlukan jadwal yang sesuai antara guru satu dengan guru lainnya dalam merencanakan pembelajaran.

\section{Keunggulan Model Shared daripada Model Pembelajaran IPA Terpadu yang Lain}

Berdasarkan kajian literatur pembelajaran IPA Terpadu model shared dan model selain shared, dapat diketahui bahwa perangkat pembelajaran yang dikembangkan masingmasing model valid, praktis, efektif, dan sangat layak untuk digunakan. Adapun masingmasing model memiliki cara sendiri untuk meningkatkan hasil belajar peserta didik aspek kognitif, afektif, dan psikomotor. Model pembelajaran IPA Terpadu model shared dan model selain shared (dalam hal ini adalah model integrated) juga dapat dijadikan alternatif model dalam meningkatkan pemahaman konsep peserta didik. Namun, tetap terdapat perbedaan yang signifikan antara penggunaan pembelajaran IPA Terpadu model shared dengan model selain shared. Salah satunya adalah kombinasi antara pembelajaran IPA Terpadu model shared dan model pembelajaran discovery learning lebih unggul dalam meningkatkan penguasaan konsep peserta didik daripada kombinasi antara model discovery learning dan pembelajaran IPA Terpadu model selain shared (dalam hal ini adalah model webbed), sedangkan untuk meningkatkan keterampilan proses sains peserta didik tidak ada perbedaan yang signifikan antara penggunaan kombinasi model discovery learning dan model shared ataupun kombinasi model discovery learning dan model selain shared (webbed).

\section{Penerapan Pelaksanaan Pembelajaran IPA Terpadu Model Shared di Indonesia}

Dalam kajian literatur pembelajaran IPA Terpadu model shared di Indonesia, diperoleh total 20 artikel tentang pembelajaran IPA Terpadu model shared di Indonesia tahun 20122021. Diantaranya adalah tiga artikel pembelajaran IPA Terpadu model shared pada jenjang SD, 15 artikel pembelajaran IPA Terpadu model shared pada jenjang SMP, dan dua artikel pembelajaran IPA Terpadu model shared pada jenjang SMA.

Berdasarkan kajian 20 artikel, dimana tiga diantaranya adalah artikel pembelajaran IPA Terpadu model shared di Indonesia pada jenjang SD, dapat diketahui bahwa salah 
satu keterbatasan penelitian yang dilakukan yaitu media yang digunakan dalam pembelajaran adalah media pop-up book. Dalam hal ini dapat diketahui bahwa model pembelajaran terpadu model shared berbantu media pop-up book dapat meningkatkan hasil belajar peserta didik. Selain itu, dilakukan juga pengembangan perangkat pembelajaran yang meliputi silabus; RPP; materi ajar; lembar kerja peserta didik; dan tes hasil belajar. Dalam hal ini, dapat diketahui bahwa perangkat pembelajaran terpadu model shared berbasis saintifik dinyatakan efektif dan berpengaruh terhadap peningkatan hasil belajar pembelajaran terpadu berbasis saintifik peserta didik.

Jumlah artikel yang dikaji tentang pembelajaran IPA Terpadu model shared di Indonesia pada jenjang SMP adalah 15 artikel. Selain pada jenjang SD, ada pula penelitian yang berfokus pada pengembangan perangkat pembelajaran pada jenjang SMP. Dimana hasil yang diperoleh menyatakan perangkat pembelajaran yang meliputi silabus, Rencana Perangkat Pembelajaran, Lembar Kerja Peserta Didik, Buku Siswa, dan instrumen tes hasil belajar dinyatakan sangat layak dan hasil belajar peserta didik aspek kognitif rata-rata dinyatakan tuntas. Selain itu, diketahui dengan mengkombinasikan pembelajaran IPA Terpadu model shared dan model pembelajaran Student Teams Achievement Division (STAD) dapat lebih meningkatkan hasil belajar aspek kognitif peserta didik. Sedangkan dengan mengkombinasikan pembelajaran IPA Terpadu model shared dan model pembelajaran discovery learning dapat meningkatkan keterampilan proses sains peserta didik. Selain mengkombinasikan pembelajaran IPA Terpadu model shared dan model discovery learning, kombinasi antara pembelajaran IPA Terpadu model shared dan model pembelajaran 7E juga dapat meningkatkan keterampilan proses sains peserta didik dan mendapat respon yang positif dari peserta didik, karena model pembelajaran 7E merupakan pembelajaran aktif yang menyebabkan peserta didik berperan penting dalam proses pembelajaran. Pembelajaran IPA Terpadu model shared juga dapat meningkatkan kemampuan literasi sains dalam aspek konten, proses, dan sikap sains, dan dapat merubah konsistensi konsep peserta didik dari tidak tahu konsep menjadi tahu konsep. Salah satu penelitian pembelajaran IPA Terpadu model shared di Indonesia pada jenjang SMP memiliki keterbatasan penelitian dalam pemilihan sampel, yaitu memperhatikan tingkat keaktifan peserta didik yang lebih tinggi. Dalam hal ini dapat diketahui bahwa peserta didik merasa lebih mudah memahami materi IPA Terpadu. Peserta didik juga berpartisipasi dalam setiap tahapan kegiatan pembelajaran IPA Terpadu model shared. Penggunaan bahan ajar yang menggunakan keterpaduan tipe shared antara dua mata pelajaran yang berbeda (IPA dan matematika) bisa menjadi alternatif dalam menyampaikan materi fisika yang sangat erat hubungannya dengan analisis dan perhitungan matematis kepada peserta didik. Penggunaan Buku Siswa IPA Terpadu model shared lebih efektif untuk aspek psikomotor daripada aspek kognitif.

Artikel pembelajaran IPA Terpadu model shared pada jenjang SMA yang dikaji berjumlah dua artikel. Dimana dalam hal ini dapat diketahui pembelajaran IPA Terpadu model shared dapat meningkatkan kecerdasan spiritual peserta didik. Selain itu juga dapat diketahui, pembelajaran IPA Terpadu model shared juga lebih unggul pada pelajaran Biologi, karena adanya pelatihan ilmu kependidikan dalam proses pembelajaran.

\section{Kendala dalam Pelaksanaan Pembelajaran IPA Terpadu Model Shared di Indonesia} Berdasarkan kajian literatur yang telah dilakukan, dapat diketahui bahwa pengetahuan guru masih kurang dalam mengembangkan perangkat pembelajaran dan merumuskan 
keterpaduan setiap mata pelajaran. Hal tersebut berpengaruh terhadap hasil belajar peserta didik yang rendah.

Secara umum, tidak ada kendala yang berarti dalam pelaksanaan pembelajaran IPA Terpadu model shared pada jenjang SD. Justru pembelajaran IPA Terpadu model shared berbantu media pop-up book disarankan untuk meningkatkan hasil belajar peserta didik. Sama halnya pembelajaran IPA Terpadu model shared pada jenjang SD, pembelajaran IPA Terpadu model shared pada jenjang SMP juga tidak ada kendala yang serius. Justru pengembangan perangkat pembelajaran IPA Terpadu model shared dinyatakan layak untuk digunakan dan diterapkan dalam pembelajaran IPA Terpadu. Begitupun juga pembelajaran IPA Terpadu model shared pada jenjang SMA, tidak ada kendala yang berarti. Justru selain meningkatkan hasil belajar peserta didik aspek kognitif, psikomotor, dan afektif, penggunaan model shared dalam pembelajaran IPA Terpadu pada jenjang SMA juga meningkatkan kecerdasan spiritual peserta didik.

\section{Alternatif Solusi Pembelajaran IPA Terpadu Model Shared di Indonesia}

Berdasarkan kajian literatur yang telah dilakukan, dapat diketahui bahwa pengetahuan guru masih kurang dalam mengembangkan perangkat pembelajaran dan merumuskan keterpaduan setiap mata pelajaran. Hal tersebut berpengaruh terhadap hasil belajar peserta didik yang rendah. Oleh karena itu, dalam hal ini dilakukan pengembangan pembelajaran IPA Terpadu model shared untuk meningkatkan hasil belajar peserta didik aspek kognitif, afektif, maupun psikomotor. Model shared juga sangat cocok bagi pembelajaran yang dalam pelaksanaannya menciptakan suatu fokus pada konsep tertentu dari penggabungan lebih dari satu mata pelajaran.

\section{Trend Penelitian Pembelajaran IPA Terpadu Model Shared di Indonesia}

Model pembelajaran IPA Terpadu model shared merupakan salah satu model yang disarankan dalam pembelajaran IPA Terpadu di Indonesia baik pada jenjang sekolah SD, SMP, maupun SMA. Pembelajaran IPA Terpadu yang dilaksanakan dengan menerapkan model shared mampu mempengaruhi hasil belajar peserta didik aspek kognitif, afektif, dan psikomotor secara positif. Selain itu, dengan mengkombinasikan model pembelajaran IPA Terpadu tipe shared dengan model pembelajaran lain seperti discovery learning, Student Teams Achievement Division (STAD), model pembelajaran 7E dapat meningkatkan keterampilan proses sains peserta didik, mendapat respon yang baik dari peserta didik, dan meningkatkan hasil belajar peserta secara signifikan, sehingga menjadi trend dalam pembelajaran masa kini.

Media atau bahan ajar merupakan alat bagi guru untuk menyampaikan suatu materi pelajaran. Selama ini, media dan bahan ajar yang biasa digunakan berupa handout, Lembar Kerja Peserta Didik, modul, dan buku ajar. Oleh karena itu, dibutuhkan inovasi baru yang akan berpengaruh terhadap respon peserta didik dalam meningkatkan hasil belajar tiap individu. Seperti contoh berdasarkan penelitian yang telah ada, yaitu pembelajaran IPA Terpadu model shared berbantu media pop-up book. Pembelajaran IPA Terpadu model shared berbantu media pop-up book ini disarankan guna meningkatkan hasil belajar peserta didik.

\section{Saran Penerapan Pembelajaran IPA Terpadu Model Shared di Indonesia}

Berdasarkan trend penelitian pembelajaran IPA Terpadu model shared di Indonesia, maka dapat disampaikan saran dalam pelaksanaan pembelajaran IPA Terpadu 
menggunakan model shared yang dikombinasikan dengan model lain yang cocok untuk suatu tema pelajaran tertentu. Misalnya model shared yang dipadukan dengan model discovery learning guna meningkatkan keterampilan proses sains peserta didik pada tema Pemanfaatan Sampah, model shared yang dikombinasikan dengan model Student Teams Achievement Division (STAD) guna meningkatkan hasil belajar peserta didik aspek kognitif, afektif, dan psikomotor pada tema Senter Plastik dan materi pokok cahaya, serta model shared yang dikombinasikan dengan model pembelajaran 7E guna meningkatkan keterampilan proses sains peserta didik pada tema Energi Biomassa. Selain itu, disarankan juga pelaksanaan pembelajaran IPA Terpadu model shared berbantu media pop-up book sebagai inovasi baru guna meningkatkan hasil belajar peserta didik.

\section{KESIMPULAN}

Berdasarkan kajian literatur pada implementasi pembelajaran IPA Terpadu model shared yang telah dilakukan, dapat disimpulkan bahwa pembelajaran IPA Terpadu model shared berdampak positif terhadap hasil belajar peserta didik meliputi tercapainya ketuntasan hasil belajar peserta didik (aspek kognitif, psikomotor, dan afektif), peserta didik lebih mudah memahami materi IPA Terpadu, meningkatkan keterampilan proses sains peserta didik, peserta didik aktif berpartisipasi dalam proses pembelajaran, meningkatkan penguasaan konsep peserta didik, meningkatkan kemampuan literasi sains, dan merubah konsistensi konsepsi peserta didik.

Materi pelajaran dalam pembelajaran IPA Terpadu model shared lebih kontekstual dibandingkan model selain shared. Berdasarkan kajian literatur pembelajaran IPA Terpadu model shared dan model selain shared, dapat diketahui bahwa perangkat pembelajaran yang dikembangkan masing-masing model sangat layak untuk digunakan. Masing-masing model memiliki cara sendiri untuk meningkatkan hasil belajar peserta didik aspek kognitif, afektif, dan psikomotor. Model pembelajaran IPA Terpadu model shared dan model selain shared (dalam hal ini adalah model integrated) juga dapat dijadikan alternatif model dalam meningkatkan pemahaman konsep peserta didik. Namun, tetap terdapat perbedaan yang signifikan antara penggunaan pembelajaran IPA Terpadu model shared dengan model selain shared, yaitu ketika kombinasi antara pembelajaran IPA Terpadu model shared dan model pembelajaran discovery learning lebih unggul dalam meningkatkan penguasaan konsep peserta didik daripada kombinasi antara model discovery learning dan pembelajaran IPA Terpadu model selain shared (dalam hal ini adalah model webbed).

\section{UCAPAN TERIMA KASIH}

Penulis ingin mengucapkan terimakasih kepada keluarga yang selalu bersedia mendukung dan memberi semangat selama proses penelitian, juga kepada dosen pembimbing atau pengampu mata kuliah yang bersangkutan yang sudah banyak membantu, memberi saran, dan kritik untuk membuat dan membantu membangun penelitian ini menjadi lebih baik, dan atas segala ilmu yang telah diberikan.

\section{DAFTAR PUSTAKA}

Agustin, N. (2019). Penerapan Model Pembelajaran Learning Cycle dalam Pembelajaran IPA Terpadu Terhadap Keterampilan Proses Sains Siswa. Tadris: Jurnal Penelitian dan Pemikiran Pendidikan Islam, 11(1): 37-52. https:/ / doi.org/10.51675/jt.v11i1.14 
Aqila, N., Ratnawulan, dan Gusnedi (2019). Pengaruh Penggunaan Buku SIswa IPA Terpadu Model Shared dengan Tema Kohesi dan Adhesi pada Lingkungan terhadap Hasil Belajar Peserta Didik Kelas VII SMPN 4 Padang. Pillar of Physics Education, 12(1): 49-56. https:/ / dx.doi.org/10.24036/4774171074

Ardianto, D. dan B. Rubini (2016). Literasi Sains dan Aktivitas Siswa pada Pembelajaran IPA Terpadu Tipe Shared. Unnes Science Education Journal, 5(1): 1167-1174. https:/ / dx.doi.org/10.15294/ usej.v5i1.9650

Cahyani, E. R., H. Fitrihidajati, dan E. Hariyono (2013). Perangkat Pembelajaran IPA Terpadu Model Shared Materi Pokok Transformasi Energi dalam Ekosistem. Pensa E-Jurnal: Pendidikan Sains, 1(02): 155-162.

Diniya (2019). Pembelajaran IPA Terpadu Tipe Integrated Melalui Model Inkuiri Terbimbing Tingkat Sekolah Menengah Pertama. JNSI: Journal of Natural Science and Integration, 2(2): 143-152. http:/ / dx.doi.org/10.24014/jnsi.v2i2.7580

Ekapti, R. F. (2016). Respon Siswa dan Guru dalam Pembelajaran IPA Terpadu Konsep Tekanan melalui Problem Based Learning. Jurnal Pena Sains, 3(2): 109-115. https:/ / doi.org/10.21107/jps.v3i2.2027

Ekapti, R. F. dan M. Ahied (2016). Konsepsi Siswa SMP dalam Pembelajaran IPA Terpadu Tipe Shared Konsep Tekanan. Prosiding Seminar Nasional Pendidikan Sains, 147-154. Surakarta: Universitas Sebelas Maret.

Ferdiana, S., R. P. Puspitasari, dan W. Budjiastuti (2013). Pengembangan Perangkat Pembelajaran IPA Terpadu Berbahasa Inggris Tipe Integrated dengan Tema Mengamati Jasad Renik dalam Setetes Air untuk Kelas VII SMP. Bioedu: Berkala Ilmiah Pendidikan Biologi, 2(1): 31-34.

Fiandi, C. O. (2015). Penerapan Model Student Team-Achievement Divisions Tipe Shared untuk Meningkatkan Kemampuan Kognitif dan Sikap Ilmiah Siswa pada Materi Pokok Cahaya. EDUSAINS, 7(2): 172-178. https:/ / dx.doi.org/10.15408/es.v7i2.1810

Fiandi, C. O. (2015). Penerapan Model Student Teams-Achievement Divisions pada Pembelajaran IPA Terpadu Tipe Shared untuk Meningkatkan Kemampuan Kognitif Siswa pada Tema Cahaya. Prosiding Simposium Nasional Inovasi dan Pembelajaran Sains, 277-280. Bandung: Sekolah Pasca Sarjana Universitas Pendidikan Indonesia.

Hidayat, Z., R. S. Sarmi, dan Ratnawulan (2020). Efektivitas Buku Siswa IPA Terpadu dengan Tema Energi dalam Kehidupan Berbasis Materi Lokal Menggunakan Model Integrated untuk Meningkatkan Kecakapan Abad 21. JEP: Jurnal Eksakta Pendidikan, 4(1): 49-56. https:/ / doi.org/10.24036/jep/vol4-iss1/415

Ihwanudin, M., B. Astuti, dan A. Yulianto (2018). Bahan Ajar IPA Terpadu Tipe Integrated Berbasis Komplementasi Ayat-Ayat Al-Qur'an. UPEJ: Unnes Physics Education Journal, 7(3): 36-42. https:// doi.org/10.15294/upej.v7i3.27674

Jamila, S. H. (2019). Model Pembelajaran Terpadu (Studi Kasus di Yayasan Muhammad Ya'qub Jombang). Autentik: Jurnal Pengembangan Pendidikan Dasar, 3(2): 73-85. https:/ / doi.org/10.36379/autentik.v3i2.35

Khasanah, L. A. I. U. (2021). Pengembangan Perangkat Pembelajaran Terpadu Tipe Shared Berbasis Saintifik untuk Meningkatkan Hasil Belajar di SD. Jurnal Elementaria Edukasia, 4(1): 14-24. http:/ / dx.doi.org/10.31949/jee.v4i1.3043

Khasanah, L. A. I. U., Subroto, W. T., dan Nasution (2018). The Development of Scientific Based-Integrated Learning Tools Type Shared in Improve Fourth Grade Student Elementary School. Proceedings International Conference on Teacher Training and Education (ICOTTE), 238-245. Malang: Universitas Islam Malang. 
Krisdiyanti, D., H. Nuroso, dan F. Reffiane (2019). Pengaruh Model Integrated Berbantu Mind Mapping Terhadap Hasil Belajar. Mimbar PGSD Undiksha, 7(2): 135-140. http:/ / dx.doi.org/10.23887/jjpgsd.v7i2.17559

Mufidah, E. (2017). Penerapan Pembelajaran IPA Terpadu Tipe Integrated pada Tema Mata Kelas VIII di SMP Negeri 1 Babat Lamongan Terhadap Peningkatan Prestasi Belajar Siswa. Jurnal Cendekia: Media Komunikasi Penelitian dan Pengembangan Pendidikan Islam, 09(01): 43-66. https://doi.org/10.37850/cendekia.v9i01.51

Nikmah, S., H. Nuroso, dan F. Reffiane (2019). Pengaruh Model Pembelajaran Terpadu Tipe Shared Berbantu Media Pop-Up Book Terhadap Hasil Belajar. Jurnal Pedagogi dan Pembelajaran, 2(2): 264-271. http:/ / dx.doi.org/10.23887/jp2.v2i2.17920

Novianti, N. dan A. Fitriani (2015). Penerapan Pembelajaran IPA Terpadu Tipe Webbed dan Shared pada Tema Pemanfaatan Sampah untuk Meningkatkan Penguasaan Konsep. Prosiding Seminar Nasional Fisika, 157-162. Jakarta: Jurusan Fisika, Universitas Negeri Jakarta.

Novianti, N. dan A. Fitriani (2016). Penerapan Pembelajaran IPA Terpadu Tipe Webbed dan Shared untuk Meningkatkan Keterampilan Proses. EDUSAINS, 8(1): 74-82. https:/ / dx.doi.org/10.15408/es.v8i1.1765

Priscylio, G. dan S. Anwar (2019). Integrasi Bahan Ajar IPA Menggunakan Model Robin Fogarty untuk Proses Pembelajaran IPA di SMP. Jurnal Pijar MIPA, 14(1): 1-12. http:/ / dx.doi.org/10.29303/jpm.v14i1.966

Qolbiyah, R. D. S., A. A. Abdullah, dan B. Setiawan (2013). Penerapan Pembelajaran IPA Terpadu Tipe Shared dengan Model Pembelajaran Kooperatif Tipe Student Team Achievement Division (Pembagian Pencapaian Tim Siswa) pada Tema Senter Plastik. Pensa E-Jurnal: Pendidikan Sains, 1(1): 47-53

Rahmiwati, S., Ratnawulan, dan Yohandri (2018). The Implementation of Integrated Natural Science Textbook of Junior High School be Charged on Caracter-based Shared Models to Improve the Competence of Learners' Knowledge. Physics Education, 335: 1-7. https://dx.doi.org/10.1088/1757-899X/335/1/012076

Rosidi. I. (2015). Pengembangan Perangkat Pembelajaran IPA Terpadu Tipe Integrated untuk Mengetahui Ketuntasan Belajar IPA Siswa SMP pada Topik Pengelolaan Lingkungan. Jurnal Pena Sains, 2(1): 14-25. https:/ / doi.org/10.21107/jps.v2i2.1348

Sakti, P. A. (2014). Implementasi Pembelajaran Terpadu Tipe Shared untuk Meningkatkan Kemampuan Berpikir Kritis dan Motivasi Belajar Siswa SMK pada Topik Limbah di Lingkungan Kerja. Unpublished Thesis. Bandung: Sekolah Pascasarjana Universitas Pendidikan Indonesia.

Suryaningsih, Y. (2016). Implementasi Pembelajaran Terpadu Tipe Shared untuk Meningkatkan Kecerdasan Spiritual Siswa. Jurnal Bio Educatio, 1(1): 64-71. http:/ / dx.doi.org/10.31949/be.v1i1.437

Trianto (2010). Mengembangkan Model Pembelajaran Tematik. Jakarta: Prestasi Pustaka Publisher.

Wiyono, S. O. dan Yuliani (2013). Pengembangan Perangkat Pembelajaran IPA Terpadu Tipe Shared pada Materi Molekul dan Perubahan Energi dalam Metabolisme Tumbuhan Hijau Kelas VIII. Pensa E-Jurnal: Pendidikan Sains, 1(1): 35-41

Y. N. A. dan Ibrahim, M. (2012). Pengembangan Perangkat Pembelajaran IPA Terpadu Tipe Integrated Berorientasi Inkuiri pada Tema Mikroba dalam Lingkungan untuk SMP Kelas VIII. Pensa E-Jurnal: Pendidikan Sains, 1(1): 130-137. 
Yusuf, M. dan A. R. Wulan (2015). Penerapan Model Pembelajaran Discovery Learning Menggunakan Pembelajaran Tipe Shared dan Webbed untuk Meningkatkan Keterampilan Proses Sains. JPPPF: Jurnal Penelitian \& Pengembangan Pendidikaan Fisika, 1(2): 19-26. https:/ / dx.doi.org/10.21009/1.01204

Zulkifli, M., Syamsu, dan S. Saehana (2016). Penerapan Model Pembelajaran Terpadu untuk Mengukur Hasil Belajar Siswa SMP Negeri 3 Palu. JPFT: Jurnal Pendidikan Fisika Tadulako, 4(1): 45-49.

\footnotetext{
* Juriyah (Corresponding Author)

Universitas Negeri Surabaya,

Jl. Ketintang, Ketintang, Kec. Gayungan, Kota Surabaya, Jawa Timur 60231, Indonesia

Email: juriyah.18047@mhs.unesa.ac.id
} 